\title{
Government Policies for the Natural Resource Management of Minerals and Coal Based on Social Welfare
}

\author{
Absori $^{1}$ Aullia Vivi Yulianingrum ${ }^{2}$ Rahmatullah Ayu Hasmiati ${ }^{3}$ Arief Budiono ${ }^{4}$ \\ 1,4 Fakultas Hukum Universitas Muhammadiyah Surakarta, Indonesia \\ 2,3 Fakultas Hukum Universitas Muhammadiyah Kalimantan Timur, Indonesia
}

\begin{tabular}{l}
\hline Info Artikel \\
\hline Keywords: \\
Policy, Coal Mining, Social \\
Welfare. \\
\hline Kata kunci: \\
Kebijakan, Pertambangan \\
Batubara, Kesejahteraan Sosial. \\
Corresponding Author: \\
Absori, E-mail: \\
absorisaroni@gmail.com \\
P-ISSN: 1412-6605 \\
E-ISSN: 2301-6426
\end{tabular}

\begin{abstract}
This research aims to describe the natural resources management policies in the mineral and coal sectors. The description is based on the social welfare value contained in Law No. 3 of 2020 concerning Amendment of Law No. 4 of 2009 concerning Mineral and Coal Mining, as well as Law No. 11 of 2020 concerning Employment and Labour Law. This research employed a normative judicial method based on law regulations that are conceptualized as principles or norms and have evolved into proper human behavior standards. Secondary data were employed by exploring literature correlated with the mineral and coal mining management law and analyzed using juridical-qualitative techniques. Subsequently, the research indicated that the Indonesian government policy in the Mineral and Coal, alongside Omnibus Laws, are unable to accommodate social welfare values and support only profitoriented businesspersons. This research is expected to proffer suggestions for the central or regional government to make regulations prior to the social welfare principle.

\begin{tabular}{l} 
Abstrak \\
\hline Penelitian ini bertujuan untuk mendeskripsikan kebijakan \\
pengelolaan sumber daya alam di sektor minerba. Uraian \\
tersebut didasarkan pada nilai kesejahteraan sosial yang tertuang \\
dalam Undang-Undang Nomor 3 Tahun 2020 tentang Perubahan \\
atas Undang-Undang Nomor 4 Tahun 2009 tentang \\
Pertambangan Mineral dan Batubara, serta Undang-Undang \\
Nomor 11 Tahun 2020 tentang Undang-Undang Ketenagakerjaan \\
dan Ketenagakerjaan. Penelitian ini menggunakan metode \\
yuridis normatif berdasarkan peraturan perundang-undangan \\
yang dikonseptualisasikan sebagai asas atau norma dan telah \\
berkembang menjadi standar perilaku manusia yang layak. Data \\
sekunder digunakan dengan menggali literatur yang \\
berhubungan dengan hukum pengelolaan pertambangan \\
mineral dan batubara dan dianalisis dengan teknik yuridis- \\
kualitatif. Selanjutnya, penelitian menunjukkan bahwa kebijakan \\
pemerintah Indonesia di bidang Mineral dan Batubara, di \\
samping Omnibus Laws, tidak mampu mengakomodasi nilai- \\
nilai kesejahteraan sosial dan hanya mendukung pengusaha \\
yang berorientasi pada keuntungan. Penelitian ini diharapkan \\
dapat memberikan saran bagi pemerintah pusat atau daerah \\
untuk membuat peraturan sebelum prinsip kesejahteraan sosial.
\end{tabular}
\end{abstract}




\section{Introduction}

Natural resources are blessings granted by God Almighty and should neither be exploited excessively nor savored by only some groups of persons. Hence, these resources are mandated for the maintenance and benefit of humans. ${ }^{1}$ The Mineral and Coal Mining, as well as Job Creation Laws, are legal products issued to address natural resource management problems in Indonesia. These laws aim to improve the economy and social welfare, as stated in article 33 paragraph (3) of the 1945 Constitution. Welfare refers to the fulfillment of basic needs, such as clothing, food, and housing (primary), alongside additional (secondary) and complementary needs (tertiary), to achieve happiness. ${ }^{2}$ However, happiness requires more than just fulfilling these basic needs, as despite sharing a common basis, humans have different desires called the hierarchy of needs, which include comfort, personality, and affection. ${ }^{3}$ According to Spicker, the majority of people's economic development denotes their welfare. The foundations of this welfare attempt to meet the demands of the hierarchy of needs, commonly referred to as basic human right. ${ }^{4}$ From this point, the gap between regulations and their implementation in natural resource management can be identified.

There are several problems concerning the management of natural resources, especially mineral and coal mining. These include 1) overlapping laws and regulations, 2) increasing mining business license area (WIUP), causing wider supervision of related activities, and 3) using customary models to resolve conflicts between indigenous peoples and business actors, especially during compensation arrangements and preserving inherited local cultural values. Other problems are 4) the abandonment of former excavations and ignoring of reclamation and post-mining obligations by companies, 5) casualties due to unreclaimed mining pits, 6) the opening of mining areas in forests, 7) environmental damage and natural disasters such as erosion, landslides, and floods, and 8) the conditions of poor people in mining areas. Poverty can be characterized by unequal economic income in society, creating a large social gap. Although business actors generate more profits, the community does not experience the benefits. ${ }^{5}$

\footnotetext{
${ }^{1}$ A. Absori, K. Dimyati, and R. Ridwan, 'Makna Pengelolaan Lingkungan Pespektif Etik Profetik', Al-Tahrir: Jurnal Pemikiran Islam, 17.2 (2017), 331-352.

2 I Gusti Ayu Ketut Rachmi Handayani and others, 'Environmental Management Strategy in Mining Activities in Forest Area Accordance with the Based Justice in Indonesia', Journal of Legal, Ethical and Regulatory Issues, 21.2 (2018), 1-8.

${ }^{3}$ L. Sperry and others, 'Spirituality in Achieving Physical and Psychological Health and Well-Being: Theory, Research, and Low-Cost Interventions', in In Low-Cost Approaches to Promote Physical and Mental Health (Springer Science + Business Media, 2007).

${ }_{4}^{4}$ P. Spicker, The Welfare State: A General Theory (California: Sage, 2000).

${ }^{5}$ Moh. Iqra Syabani Korompot, Sholahuddin Al-Fatih, and David Pradhan, 'The Principle of Equality Before the Law in Indonesian Corruption Case: Is It Relevant?', Journal of Human Rights, Culture and Legal System, $1.3(2021)$.
} 
Consequently, the government enacted various laws and regulations related to natural resource management, especially Mineral and Coal Mining. These include Law Number 3 of 2020 concerning Amendments to Law Number 4 of 2009 concerning Mineral and Coal Mining, Law Number 11 of 2020 concerning Job Creation, Law Number 11 of 2009 concerning Social Welfare, as well as various government regulation products and their derivatives. However, these laws and regulations have been unable to provide even distribution of justice and welfare.

The various problems and phenomena listed above, as well as issues of environmental damage, have triggered public distrust of the government's ability to protect people's welfare from the visible impacts of mining activities, including casualties and environmental damage. ${ }^{6}$ Meanwhile, the implemented mining business management efforts have been unable to fulfill the basic welfare principles. Based on these empirical facts from a liberalistic view, welfare is oriented towards individualism, egoism, and ignores altruism or concern for others. Hence, the construction of natural management oriented towards ethical environmental values, mutual benefit, and morality are required to achieve community welfare.

Therefore, this paper focuses on exploring the policies for natural resource management of minerals and coal in Indonesia and its concept based on social welfare. Through these policies, the purpose of natural resource management for people's welfare can be used as a guideline for the government, stakeholders, business actors, and the community to promote appropriate governance. They are also expected to create environmental recovery from excessive mining activities, damage to the ecosystem, and the degradation of the interests of border communities that require legal force as a policy regulation

\section{Methods}

This analytical descriptive research used a normative juridical or legal approach by examining library materials as the primary data. ${ }^{7}$ Provisions of laws, regulations, theories, and doctrines regarding the natural resource management of minerals and coal were studied. Meanwhile, secondary data sources were employed by reviewing primary legal materials such as the 1945 Constitution of the Republic of Indonesia, alongside the Law on Minerals and Coal Mining. Secondary legal resources obtained from reference books, scientific journals, articles, newspapers, dissertations, and related papers were used to explain the primary legal materials. Secondary materials were obtained from electronic libraries on the internet to find and access the required information.

${ }^{6}$ Devi Triasari, 'Right to Sanitation: Case Study of Indonesia', Journal of Human Rights, Culture and Legal System, 1.3 (2021).

7 Soerjono Soekanto, Pengantar Penelitian Hukum (Jakarta: UI-Press, 2011). 
Subsequently, the data acquired from the primary sources, theories, and doctrines were analyzed qualitatively. ${ }^{8}$

\section{Results and Discussion}

\section{The Natural Resource Management Policy of Minerals and Coal in Indonesia}

The formulation of an appropriate government policy is a crucial matter in natural resource management. Policies are government instruments containing a series of actions with a specific purpose that must be complied with in solving a problem. ${ }^{9}$ Natural resource management policies, especially for coal mining, are aimed at the present and future welfare. The involved systems must meet the rules of good and correct management, including a focus on various environments such as physical and chemical, the social and economic aspects of the surrounding community, and the post-mining areas. ${ }^{10}$

Mining sector policies in Indonesia lead to: ${ }^{11}$

a. Implementing priority fulfillment of minerals and coal for domestic needs;

b. Providing certainty of transparency in mining activities;

c. Conducting developed supervision and coaching;

d. Encouraging increased investment and state revenues;

e. Encouraging the development of added value for mining commodity products; and

f. Paying attention to environmental sustainability through post-mining management and monitoring.

Regulations and policies must be formulated to allow law enforcement to achieve national and state ideals and goals. Hence, the concept of sustainable development in a prismatic legal bond is a solution to its idealism. According to Absori, this can be achieved by considering the ecosystem's carrying capacity and protecting the function of natural resources and the environment during political decision-making. Other essential steps are establishing concrete (political) policy steps to realize community justice in accessing natural resources. This can help prevent and overcome prolonged conflicts that can lead to national disintegration. Also, the development can be assisted

\footnotetext{
8 Soekanto.

${ }^{9}$ C. J. Andrews, 'Rationality in Policy Decision-Making', in Handbook of Public Policy Analysis, ed. by Frank Fischer, Gerald J. Miller, and Mara S. Sidney (New York: CRS Press: Taylor \& Francis Group, 2017).

10 Rachmad Safa'at, "'Rekonstruksi Politik Hukum Tata Kelola Pertambangan Mineral Dan Batubara Berbasis Keadlian Sosial Dan Berkelanjutan Lingkungan"' (Universitas Brawijaya (UB) Malang., 2020).

11 M. B. Salinding, 'Prinsip Hukum Pertambangan Mineral Dan Batubara Yang Berpihak Kepada Masyarakat Hukum Adat', Jurnal Konstitusi, 16.1 (2019), 148-69.
} 
by reconstructing and reconsolidating a solid and integrated institution for managing natural resources and the environment and preparing development-related programs within a certain. ${ }^{12}$

The supply of mineral and coal resources is utilized for fulfilling domestic needs, namely national energy security. According to Suryaningsi:

"Energy is a basic unavoidable human need, and its sufficiency highly affects a nation's present and future survival. This necessitates the achievement of national energy security, especially for coal. Therefore, a management policy direction is needed as a basis for optimizing the utilization of mineral and coal resources." 13

Kwik Kian Gie in Indah Dwi Qurbani also highlighted that the amendment to Article 33 of the 1945 Constitution of the Republic of Indonesia is closely related to liberalization in the natural resource management sector. This justifies the liberalization process in this sector and minimizes the state's role in procuring public goods and services needed by the people. Although procurement requiring large funds is left to the private sector, monopolists emerge since those with capital are foreign companies. This forces people who need the funds to pay a high price, as there is no longer any state government obligation to cooperate through tax instruments. This is due to changes in legal orientation, including the development of perfect market mechanisms, liberalization, privatization, and globalization. ${ }^{14}$

The policy direction for mineral and coal resources is inseparable from the nation's goals and objectives to be achieved through the authorities. Generally, the orientation of policies and regulations should be similar to the perception of Mahfud MD. According to this politician, the formulation and law enforcement of regulations or policies must be adopted to achieve the national and state ideals and goals. This means efforts to make the law a process of achieving goals and objectives are needed. ${ }^{15}$ Any national policy is based on and guided by the following mindset or basic framework:

a. First, it must adhere to the national ideals, namely a just and prosperous society based on Pancasila.

b. Second, national legal politics must be aimed at achieving state goals, namely:

1) Protect the entire Indonesian nation and homeland;

12 A Absori, K Dimyati, and R Ridwan, 'Deklarasi Pembangunan Berkelanjutan Dan Implikasinya Di Indonesia', Jurnal Ilmu Hukum, 9.1 (2006), 39-52.

${ }^{13}$ Suryaningsi, Eksistensi Negara Atas Pengelolaan Dan Pengusahaan Sumber Daya Minera Dan Batu Bara (Yogyakarta: Kreasi Total Media, 2017).

${ }^{14}$ I Gusti Ayu Ketut Rachmi Handayani, Hilaire Tegnan, and Abdul Kadir Jaelani, 'Strenghtening the Implementation EOR (Enhanced Oil Recovery) Model Regulation as AJustice Oil Public Policy', International Journal of Business, Economics and Law, 18.2 (2019), 23-29.

15 Sunaryati Hartono, Politik Hukum Menuju Satu Sistem Hukum Nasional (Bandung: Alumni, 1991). 
2) Promote the general welfare;

3) Educate people; and

4) Implement a world order based on freedom, eternal peace, and social justice.

c. Third, national legal politics must be guided by the following Pancasila values as the basis of the state, namely:

1) Based on religious morals;

2) Respect and protect human rights without discrimination;

3) Unite all national elements with their primordial ties;

4) Putting power under the people's control; and

5) Building social justice.

d. Fourth, national legal politics must be guided by the need to:

1) Protect all national elements for the sake of the country's integration or integrity;

2) Realize social justice in the economy and society;

3) Realize democracy (sovereignty of the people) and nomocracy (sovereignty of law); and

4) Create religious tolerance based on civility and humanity.

e. Fifth, the national legal system, such as interests, social values, and the concept of justice in a prismatic legal bond by taking the good elements, should be based on Pancasila to achieve goals with these foundations and guidelines.

Currently, Indonesia's natural resource management policies are convenient for domestic and foreign private investors. The government prioritizes procedures that facilitate investments from new mining entrepreneurs by simplifying the bureaucracy, providing security facilities, and even adjusting several state laws to ease their entry into Indonesia. This corresponds with Ahmad Redi's statement that private-sector mineral and coal investors increasingly moved to Indonesia over the past decade. Two main factors that stimulate their interests are:

a. Interesting geology; and

b. Investment-friendly regulatory framework.

Subsequently, the government introduced a new mining regulation based on an online single submission (OSS) system to promote private sector investments. Meanwhile, the most crucial reasons for managing investments in a country are: 
a. The destination country's legal basis and legitimacy, which facilitates the development of national minerals,

b. Regulatory and fiscal systems, and

c. The government's institutional framework. ${ }^{16}$

The aforementioned changes are also common in resource-rich countries with emerging and transition economies, where they emphasize their appeal to private mineral investors. An example of such changes is the increasing activities of transnational mining and exploration companies in Asia. This revision of the mineral regulatory system proves the government's tendency to deviate from restricting to encouraging foreign investment in the natural resources sector.

Saltzman and Thompson stated that the orientation towards regulations on mining management is intended to anticipate refocused exploration and mining strategies in transnational companies. Also, it is aimed at allowing increased mining activities in natural resource-rich areas. ${ }^{17}$

However, these regulatory changes have occasionally created new uncertainties for the mining industry. This problem is partly due to the different legal approaches adopted by countries, which complicate the acquaintance of transnational companies with each regulatory systemm. ${ }^{18}$ Therefore, the current mining management rules have a paradigm of regulating investments in mineral activities, as well as establishing the rights, obligations, and restrictions of companies, individuals, and governments. The mineral activities covered by the mining regulations include prospecting, exploration, and the processing of discovered metals and minerals.

Meanwhile, the amendments to these regulations reflect changes in the national mineral policy, such as lifting the restrictions on foreign direct investment in the minerals sector and identifying the government's role o as a regulator rather than a producer. The basic framework of mining regulations covers the main aspects of mining activities. These include 1) government authority over the sector, 2) restrictions on certain activities, 3) exploration and mining rights, and 4) environmental requirements. ${ }^{19}$ On examining the legal aspects of natural resource exploration in the mining sector, the following concepts are currently present:

${ }^{16} \mathrm{~K}$. Naito and others, 'Legal Aspects of Exploration and Mining: A Comparative Table of Mining Law in Asia', Journal of Energy \& Natural Resources Law, 17.1 (1999), 1-12.

17 J. Saltzman and B. H. Thompson, Environmental Law and Policy: Concepts and Insights (New York: Foundation Press, 2013).

${ }_{18}$ Guo Wei-Ci and Wu Chao A., 'Comparative Study on Coal Mine Safety between China and the US from a Safety Sociology Perspective, First International Symposium on Mine Safety Science and Engineering', Procedia Engineering, 26 (2011), 2003 - 2011.

19 I. Mustalahti and others, 'Responsibilization in Natural Resources Governance: A Romantic Doxa?', Forest Policy and Economics, 111 (2020). 
Table 3.1 Natural Resource Management Regulations in Indonesia

\begin{tabular}{ll}
\hline & \multicolumn{1}{c}{ Legal Aspect } \\
\hline Government & 1) Natural resource ownership; \\
authority & 2) Authority is granted to government officials; \\
& 3) Enforcement, penalties, and fines; \\
& 4) Authority to negotiate mining contracts. \\
\hline Limitation of mining & 1) Qualifications for the authorization to explore, mine and \\
activities & 2) process; \\
2) & 3) The type of mine is subject to special controls or conditions; \\
4) Areas subject to special controls or provisions; \\
5) Land access; \\
6) Conflicting land-use resolutions. \\
\hline 1) The maximum area of exploration or mining; \\
obligations & 2) Period for exploration and mining and renewal of the rights; \\
3) Cancellation or termination of rights; \\
4) Exploration area release; \\
5)Minimum exploration expenditure obligation; \\
6) Production requirements; \\
7) Ownership security; \\
8) Reporting; \\
9) Transfer of rights; \\
10) Royalties \\
1) Mitigation of environmental impacts; \\
2) Social or community impact; \\
3) Monitoring and reporting; \\
4) Reclamation; \\
5) Post-closure obligations.
\end{tabular}

Source: Processed data

\section{The Government Policy Concept for the Natural Resource Management of Mineral and Coal Based on Social Welfare}

Generally, the concept of natural resource management is thought to have existed throughout civilization. The story of Noah's Ark is considered by many as the beginning of nature's protection of human welfare. ${ }^{20}$ Hence, natural resource management in Indonesia is an important part of the government's economic development agenda. One of the policies implemented is the issuance of regulations on natural resource management. Meanwhile,

${ }^{20}$ Abdul Kadi Sabaruddin, 'Peranan Pemerintah Daerah Dalam Melindungi Fungsi Kawasan Hutan Lindung Sungai Wain Kota Balikpapan’ (Universitas Gadjah Mada, 2018). 
government agendas are perceived to acquire serious attention from the authorities during a certain period.

Based on the results of the previous discussion, policies for the natural resource management of mineral and coal mining cannot be resolved solely through a formal regulatory approach involving licensing, authority, supervision, sanctions. Instead, the resolution must be performed through a conceptual approach that presents social welfare as the nation's ideals and law (rechtidea). ${ }^{21}$

According to Harun, the social welfare concept is the most ideal indicator of legal development based on legislation drafts, policies, and other instruments. Hence, the authorities' accountability to the Pancasila law is essential, where a provision and action of the Indonesian government contains several characteristics. These are (a) the state takes responsibility for social welfare implementation, (b) relies on the economic sector, (c) allows for selfdevelopment to improve the quality of life, and (d) fosters the right to work with fair and proper remuneration and treatment. Other characteristics are (e) the right to participate in determining state policies, (f) utilizing natural resources for every individual's prosperity, $(\mathrm{g})$ improving the physical and mental quality of life for all generations, $(\mathrm{h})$ maintaining poor and neglected children. Also included are (i) developing a social security system, (j) empowering the weak and underprivileged, and (k) providing health and public facilities. ${ }^{22}$ Based on these indicators, opportunities for selfdevelopment, alongside fair and proper rewards and treatment during employment, are unfortunately ruled out. The reason is that the government employs numerous foreign workers in the mining sector despite the increasing unemployment rate. ${ }^{23}$

In addition, the democratic system in Indonesia today currently lacks deliberative characteristics as well as the principle of deliberation guided by a good common will. Therefore, the democratic praxis is nearly always distorted towards the elite party's political dominance, pragmatic political orientation, and state administrator disharmony, resulting in political commotion among state elites, or even worse, anarchism. ${ }^{24}$

According to Absori, the government is considered to only handle political issues while issuing economic policies that oppose the environment. As a result, environmental problems such as pollution and environmental damage

${ }^{21}$ Hendry Julian Noor, Kardiansyah Afkar, and Henning Glaser, 'Application of Sanctions Against State Administrative Officials Failing to Implement Administrative Court Decisions', Bestuur, 9.1 (2021), 53-67.

${ }_{22}^{2}$ H. Harun, Rekonstruksi Rezim Perizinan Usaha Industri Di Indonesia Prospektif Kesejahteraan Sosial (UMS Press, 2007).

${ }^{23}$ Nur Putri Hidayah, Quincy R Cloet, and David Pradhan, 'The Implementation of Labor Development Principles According to Job Creation Law as a Reason to Protect Wages Rights', Bestuur, 9.1 (2021), 68-76.

${ }^{24}$ Kaelan, Inkonsistensi Dan Inkoherensi Dalam UUD 1945 Hasil Amandemen (Kajian Filosofis -Yuridis) (Yogyakarta: MPR.RI, 2007). 
in several areas are not managed completely. These government policies that neglect the environment have resulted in various damage and natural disasters that occur successively in almost all parts of Indonesia. 25

The potential for hyper-regulated natural resource regulations creates a legal situation that leads to multiple interpretations and problems with welfare and the environment, supposing the government succeeds in realizing its vision and mission. ${ }^{26}$ This proces in weakening the effectiveness of the regulation implementation, which eventually creates disharmony between various regulations. One of the tendencies is that formulating regulations appears to be the most effective medicine for overcoming the existing problems. Hence, numerous problems are to be regulated, and the real problem of law enforcement is ignored. ${ }^{27}$ The solution, which is unable to separate the reaction and response, yields a hyper-regulated pattern due to multiple interpretations by the authorities that are considered biased, according to moral values.

The reasons Natural Resource Laws often conflict and have not prioritized material democratic values are as follow:

a. The fulfillment of the integration of natural resource management principles is minimal and often contradictory.

b. The regulatory contents are different and conflict or overlap.

c. The Constitutional Court regulates the limits and scope of the content material, redefines the norm, and explains the applicability of the principle.

d. The coherence of lex generis and lex specialis is not very visible, considering they rarely correlate..$^{28}$

Generally, the function of managing natural resources (beheersdaad) for the people's greatest prosperity is manifested through the synergy of the central and regional state government roles. Therefore, every formulated policy must rely on the constitution, and the government should organize public goods and services to improve development efficiency and effectiveness. The government employs policies to execute the constitutional mandate. This includes altering Law Number 4 of 2009 concerning Mineral and Coal Mining to Law Number 3 of 2020, alongside the formulation of the Omnibus law in

25 Brian Baxter, A Theory of Ecological Justice (Abingdon: Routledge, 2005).

${ }^{26}$ M Azhar, 'Omnibus Law Sebagai Solusi Hiperregulasi Menuju Sonkronisasi Peraturan Per-UndangUndangan Di Indonesia', Administrative Law and Governance Journal, 2.1 (2019), 170-78.

27 A Redi, 'Dinamika Konsepsi Penguasaan Negara Atas Sumber Daya Alam', Jurnal Konstitusi, 12.2 (2016), 401-21 <https://doi.org/DOI:10.31078/jk12210>.

28 S. Suhartono, 'Desentralisasi Pengelolaan Sumber Daya Alam Untuk Mewujudkan Kesejahteraan Masyarakat', DiH: Jurnal Ilmu Hukum, 9.18 (2013). 
Law Number 11 of 2021 concerning Job Creation. Table 2 below presents the differences between the old Mineral and Coal Law and the Job Creation Act:

Table 3.2 The Differences between Mineral and Coal Mining Law (UU Minerba) and Job Creation Law (UUCK)

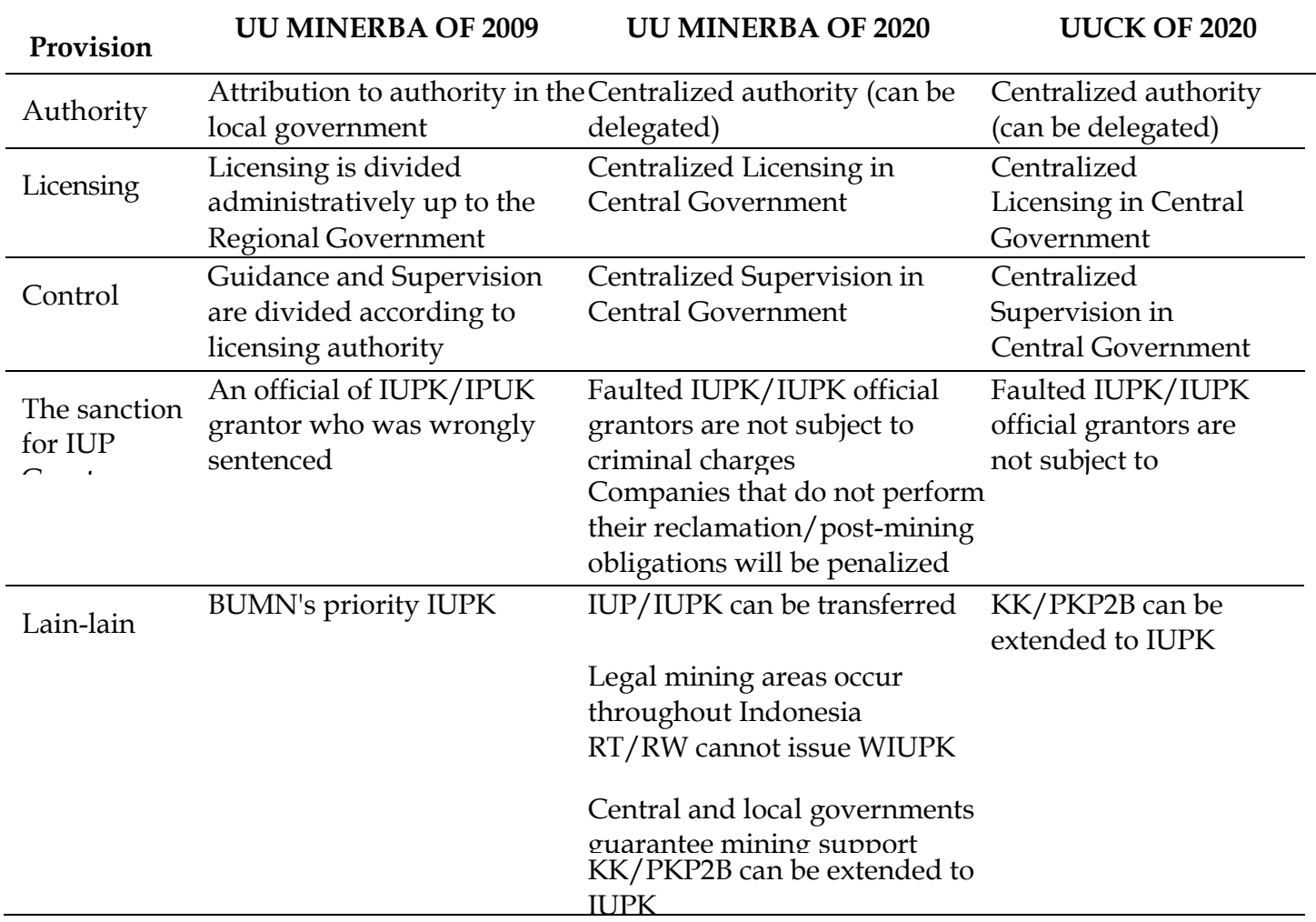

The table above shows that the government's rules for the natural resource management of mineral and coal mining only concern licensing, authority, supervision, and sanctions for licensing officials. This creates a big regulation gap in the Omnibus law, resulting in implementation weaknesses. Consequently, the new Law on Mineral and Coal Mining amends the article regarding the government's authority and centralizes licenses and other regulations. This indicates the degradation of the regional government's authority towards the principle of decentralization associated with autonomy signified in the 1945 Constitution of the Republic of Indonesia. Hence, the control of minerals and coal by the central government is one of the characteristics of a centralized state. In addition, the Mineral and Coal Mining Law contains articles on assisting local governments in several areas. These are to a) make regional regulations on mineral and coal mining management, b) permit mining business members, c) research and collect data on resources, d) supervising business production, and e) supervising post-mining land 
reclamation. However, the assistance task is invalidated with the enactment of the Job Creation Act, evidencing the degradation of regional autonomy. ${ }^{29}$

Furthermore, observations of the legal development in natural resources tend to be capitalist and liberal. However, this conflicts with the state's ideology, as it possesses the highest power organization and must be placed as the authority holder to conduct regulation, control, and utilization. This can be performed by managing natural resources as morally as possible and in the common interest to enable the realization of social welfare.

The natural resource management policy concept of mineral and coal, based on social welfare, is summarized in the scheme below:

Figure 3.1 Schema of Concept of Natural Resource Management Policy

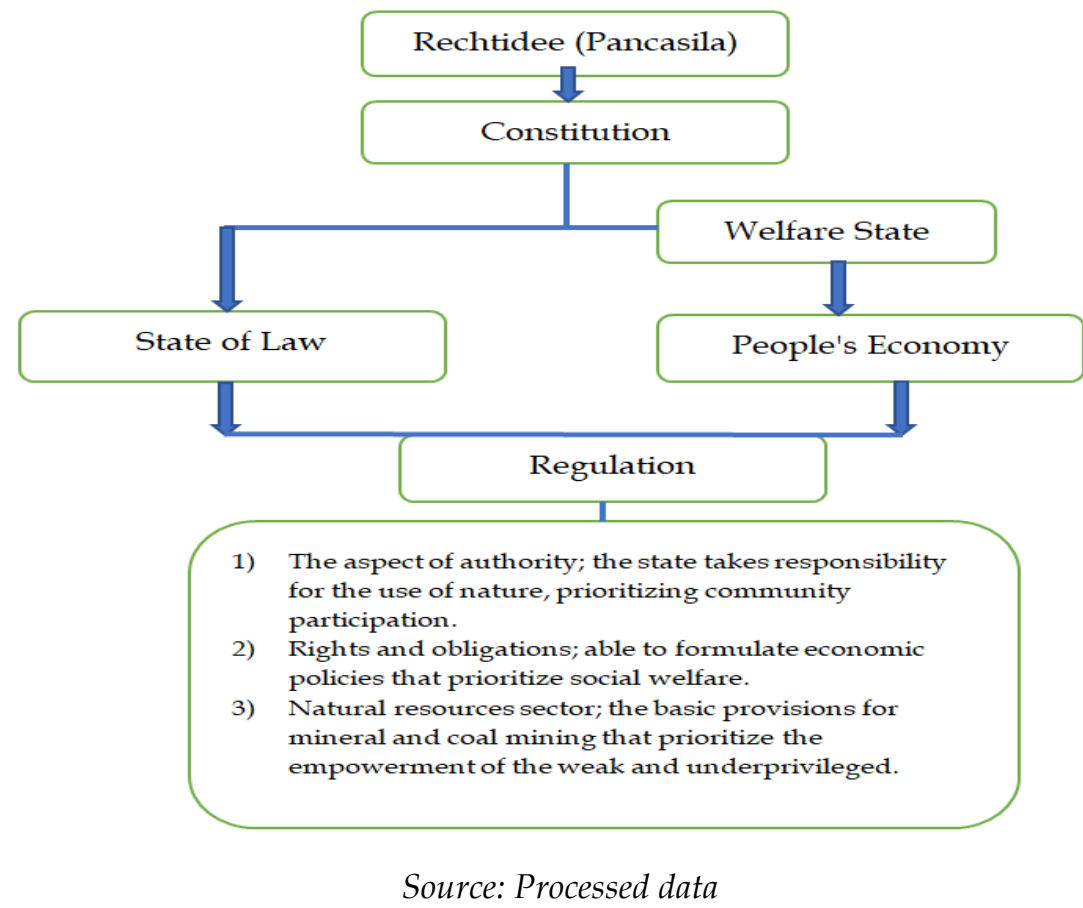

Figure 3.1 above illustrates that the social welfare concept is an important part of the nation's legal ideals. The Indonesian state always echoes people's protection while educating and participating toward the establishment of world order. Although these goals are founded on state values, namely Pancasila, which is based on God, Humanity, Unity, Democracy, and Justice, the nation has an attachment to globalization, which may view management differently. Indonesia, like other countries, is inseparable from its sectors, including natural resources and the economy. However, there is a bias in these relationships related to the people's ideology concerning materialistic

${ }^{29}$ Handayani and others. 
understanding and capitalism, which ultimately affects several regulations and policies. This nation has a source of material law in terms of the constancy of adab and cultural values, which are consequently considered important for state protection of people's rights. Ideology and legal ideals for welfare share the same picture regarding natural resources, with an emphasis on the economy and welfare orientation. Therefore, the state has a major role in strengthening the legal ideals and ideology of Indonesia by functioning as a social responsibility that creates overall welfare for the people.

\section{IV.Conclusion}

The current government policy for natural resource management of mineral and coal mining prioritizes ease of business investment through bureaucracy simplification, providing security facilities. Also, it adjusted several state law products to facilitate the entry of mining sector investors into Indonesia through changes to the Mineral and Coal Mining, alongside Omnibus Laws. The concept of these regulations should not favor profit-oriented business actors only. Hence, they should include social welfare-based management authority policies, the implementation of government rights and obligations in the natural resource field, prioritize participation policies and social care, and empower the weak and underprivileged.

\section{Refrences}

Absori, A., K. Dimyati, and R. Ridwan, 'Makna Pengelolaan Lingkungan Pespektif Etik Profetik', Al-Tahrir: Jurnal Pemikiran Islam, 17.2 (2017), 331-352 Absori, A, K Dimyati, and R Ridwan, 'Deklarasi Pembangunan Berkelanjutan Dan Implikasinya Di Indonesia', Jurnal Ilmu Hukum, 9.1 (2006), 39-52

Andrews, C. J., 'Rationality in Policy Decision-Making', in Handbook of Public Policy Analysis, ed. by Frank Fischer, Gerald J. Miller, and Mara S. Sidney (New York: CRS Press: Taylor \& Francis Group, 2017)

Azhar, M, 'Omnibus Law Sebagai Solusi Hiperregulasi Menuju Sonkronisasi

Peraturan Per-Undang-Undangan Di Indonesia', Administrative Law and Governance Journal, 2.1 (2019), 170-78

Baxter, Brian, A Theory of Ecological Justice (Abingdon: Routledge, 2005)

Handayani, I Gusti Ayu Ketut Rachmi, Adi Sulistiyono, Tommy Leonard, Ardi Gunardi, and Fatma Ulfatun Najicha, 'Environmental Management Strategy in Mining Activities in Forest Area Accordance with the Based Justice in Indonesia', Journal of Legal, Ethical and Regulatory Issues, 21.2 (2018), 1-8

Handayani, I Gusti Ayu Ketut Rachmi, Hilaire Tegnan, and Abdul Kadir Jaelani, 'Strenghtening the Implementation EOR (Enhanced Oil Recovery) Model Regulation as AJustice Oil Public Policy', International Journal of Business, Economics and Law, 18.2 (2019), 23-29 
Hartono, Sunaryati, Politik Hukum Menuju Satu Sistem Hukum Nasional (Bandung: Alumni, 1991)

Harun, H., Rekonstruksi Rezim Perizinan Usaha Industri Di Indonesia Prospektif Kesejahteraan Sosial (UMS Press, 2007)

Hidayah, Nur Putri, Quincy R Cloet, and David Pradhan, 'The Implementation of Labor Development Principles According to Job Creation Law as a Reason to Protect Wages Rights', Bestuur, 9.1 (2021), 68-76

Kaelan, Inkonsistensi Dan Inkoherensi Dalam UUD 1945 Hasil Amandemen (Kajian Filosofis -Yuridis) (Yogyakarta: MPR.RI, 2007)

Korompot, Moh. Iqra Syabani, Sholahuddin Al-Fatih, and David Pradhan, 'The Principle of Equality Before the Law in Indonesian Corruption Case: Is It Relevant?', Journal of Human Rights, Culture and Legal System, 1.3 (2021)

Mustalahti, I., V. Gutiérrez-Zamora, M. Hyle, B. P. Devkota, and N. Tokola, 'Responsibilization in Natural Resources Governance: A Romantic Doxa?', Forest Policy and Economics, 111 (2020)

Naito, K., J. M. Otto, D. N. Smith, and H. Myoi, 'Legal Aspects of Exploration and Mining: A Comparative Table of Mining Law in Asia', Journal of Energy $\mathcal{E}$ Natural Resources Law, 17.1 (1999), 1-12

Noor, Hendry Julian, Kardiansyah Afkar, and Henning Glaser, 'Application of Sanctions Against State Administrative Officials Failing to Implement Administrative Court Decisions', Bestuur, 9.1 (2021), 53-67

Redi, A, 'Dinamika Konsepsi Penguasaan Negara Atas Sumber Daya Alam', Jurnal Konstitusi, $12.2 \quad$ (2016), <https://doi.org/DOI:10.31078/jk12210>

Sabaruddin, Abdul Kadi, 'Peranan Pemerintah Daerah Dalam Melindungi Fungsi Kawasan Hutan Lindung Sungai Wain Kota Balikpapan' (Universitas Gadjah Mada, 2018)

Safa'at, Rachmad, “"Rekonstruksi Politik Hukum Tata Kelola Pertambangan Mineral Dan Batubara Berbasis Keadlian Sosial Dan Berkelanjutan Lingkungan"' (Universitas Brawijaya (UB) Malang., 2020)

Salinding, M. B., 'Prinsip Hukum Pertambangan Mineral Dan Batubara Yang Berpihak Kepada Masyarakat Hukum Adat', Jurnal Konstitusi, 16.1 (2019), 148-69

Saltzman, J., and B. H. Thompson, Environmental Law and Policy: Concepts and Insights (New York: Foundation Press, 2013)

Soekanto, Soerjono, Pengantar Penelitian Hukum (Jakarta: UI-Press, 2011)

Sperry, L., L. Hoffman, R. H. Cox, and B. E. Cox, 'Spirituality in Achieving Physical and Psychological Health and Well-Being: Theory, Research, and Low-Cost Interventions', in In Low-Cost Approaches to Promote Physical and Mental Health (Springer Science + Business Media, 2007)

Spicker, P., The Welfare State: A General Theory (California: Sage, 2000)

Suhartono, S., ‘Desentralisasi Pengelolaan Sumber Daya Alam Untuk 
Mewujudkan Kesejahteraan Masyarakat', DiH: Jurnal Ilmu Hukum, 9.18 (2013)

Suryaningsi, Eksistensi Negara Atas Pengelolaan Dan Pengusahaan Sumber Daya Minera Dan Batu Bara (Yogyakarta: Kreasi Total Media, 2017)

Triasari, Devi, 'Right to Sanitation: Case Study of Indonesia', Journal of Human Rights, Culture and Legal System, 1.3 (2021)

Wei-Ci, Guo, and Wu Chao A., 'Comparative Study on Coal Mine Safety between China and the US from a Safety Sociology Perspective, First International Symposium on Mine Safety Science and Engineering', Procedia Engineering, 26 (2011), $2003-2011$ 